AL-MASHRAFIYAH: Jurnal Ekonomi, Keuangan, dan Perbankan Syariah

ISSN (p): 2597-4904 ISSN (e) : 2620-5661

Volume 3, Nomor 2, Oktober (2019), h.159-174

https://doi.org/10.24252/al-mashrafiyah.v3i2.9869

\title{
KETERKAITAN LEMBAGA KEUANGAN MIKRO SYARIAH DENGAN AGENDA SUSTAINABLE DEVELOPMENT GOALS (SDGs)
}

\author{
Trimulato \\ Prodi Perbankan Syariah, Universitas Islam Negeri Alauddin Makassar \\ trimsiuii@yahoo.co.id
}

\section{Nuringsih}

Prodi Perbankan Syariah, Universitas Muhammadiyah Pare-Pare

inchisyafitri@gmail.com

\section{Keywords: \\ BPRS, BMT, \\ Sustainable \\ Development \\ Goals (SDGs), \\ Islamic \\ microfinance}

\section{ABSTRACT}

In February 2018, growth of financing by 52.9 percent. Islamic microfinance institutions have a role in increasing people's economic income. The goal sustainable development or commonly called Sustainable Development Goals (SDGs), its have 17 goals achieved until 2030. Goals is bring prosperity all levels society. It is line with existence Islamic microfinance institutions to improve standard living and public welfare. Type this paper is qualitative method, used is qualitative descriptive analysis, describes growth Islamic microfinance institutions BPRS and BMT institutions. Describes SDGs have objective conformity with BPRS and BMT. Results this paper indicate growth Islamic microfinance institutions, where there are component BPRS grow 10 percent. Results show are financing aspects grow 17.1 percent. BMT financial ratio remaining operating grew by 403.5 percent. Study provides information that Islamic financial institutions are accordance with achievement program SGDs related increasing income and economic activities can realized with presence welfare. Form role sharia financial institutions, easy access capital and socialization introduction financial investment.

\section{Kata Kunci:} BPRS, BMT, Sustainable Development Goals (SDGs), Keuangan Mikro Syariah.

\section{ABSTRAK}

Pada Februari 2018 pertumbuhan pembiayaan menunjukkan yang tumbuh sebesar 52,9 persen. Lembaga keuangan mikro syariah memiliki peran dalam meningkatan pendapatan ekonomi masyarakat. Tujuan dari pembangunan berkelanjutan atau yang biasa disebut Sustainable Development Gols (SDGs). SDGs memiliki 17 tujuan yang ingin dicapai sampai tahun 2030. Tujuan ini sejalan dengan keberadaan lembaga keuangan mikro syariah untuk meningkatkan taraf hidup masyarakat dan meningkatkan kesejahteraan. Artikel ini menggunakan metode kualitatif dengan teknik deskriptif, menguraikan pertumbuhan lembaga keuangan mikro syariah yaitu BPRS dan BMT. Yang dikaitkan Sustainable Development Goals (SDGs). Hasil menunjukkan pertumbuhan lembaga keuangan mikro syariah, beberapa komponen pada BPRS tumbuh di atas 10 persen. Pertumbuhan pembiayaan tumbuh sebesar 17,1 persen. Sisa hasil usaha yaitu sebesar 403,5 persen. Peran lembaga keuangan syariah dalam pencapaian SGDs meningktakan pendapatakn dan usaha masyarakat untuk menghadirkan kesejahteraan. Melalui akses keuangan baik dalam bentuk memberikan kemudahan akses modal dan pengenalan produk investasi, masyarakat dapat meningkatkan pendapatan. 
Trimulato, dan Nuringsih. Keterkaitan Lembaga Keuangan Mikro Syariah...

\section{PENDAHULUAN}

Pada dasarnya setiap manusia selalu menginginkan kehidupannya di dunia ini dalam keadaan bahagia, baik secara material maupun spiritual, individual maupun sosial. Namu dalam praktiknya kebahagiaan multi dimensi ini sangat sulit diraih karena keterbatasan kemampuan manusia dalam memahami dan menerjemahkan keinginannya secara komprehensif, keterbatasan dalam menyeimbangkan antara aspek kehidupan maupun keterbatasan sumber daya yang bisa digunakan untuk meraih kebahagiaan tersebut. Masalah ekonomi hanyalah merupakan satu bagian dari aspek kehidupan yang diharapkan akan membawa manusia kepada tujuan hidupnya.(P3EI UII,2008).

Syariat Islam memberikan acuan kepada pengikutnya tentang prinsip-prinsip dasar dalam perilaku ekonomi individu yang mengarah pada tujuan-tujuan umum (maqashid alsyariah), yaitu mewujudkan kesejahteraan masyarakat. Dari situ, Islam memberikan ruang cukup luas bagi para ilmuan untuk melakukan kajian mendalam dan serius dalam banyak bidang, termasuk studi tentang ekonomi Islam, untuk memilih strategi yang sesuai dengan tahap-tahap perkembangan ekonomi dan sosial yang ada. Syariat Islam memberikan ruang untuk dilakukan kontekstualitas (ijtihad) dengan tidak melakukan pelanggaran secara esensial. Kajian itu, agar Islam menjadi produktif (Islam Empiris). Khasanah Islam yang memberikan ruang kepada ilmuan muslim untuk melakukan kajian mendalam sehingga mampu mengembangkan keilmuan Islami yang maslahah.(Minarni, 2015).

Dalam pandangan Islam, eksistensi kehidupan manusia tidak terlepas dari naluri kehidupan manusia yang dibawa sejak lahir terdiri dari 3 hal yaitu: (Gita, 2006) 1. Naluri mempertahankan diri (ghorizatul baqa) Naluri memperetahankan diri untuk kelangsungan hidup diberikan Allah kepada semua makhluk hidup termasuk manusia. 2. Naluri melangsungkan keturunan (ghorizatun nau') Naluri untuk melangsungkan keturunan diberikan Allah kepada semua makhluk hidup sama dengan naluri mempertahankan diri. 3. Naluri beragama (ghorizatun taddayun) Naluri beragama hanya diberikan kepada ciptaan Allah makhluk terbaik di muka bumi yang diberi nama manusia. Bukti bahwa manusia memiliki naluri beragama adalah ketika terjadi kondisi yang sangat menakutkan maka dalam hati terjadi kondisi yang sangat menakutkan maka dalam hati mengatakan adanya yang maha kuasa di muka bumi ini dan meminta perlindungan dari-Nya.

Ekonomi Islam dibangun atas dasar agama islam, karenanya ia merupakan bagian tak terpisahkan integral dari agama islam. Sebagai derivasi dari agama islam, ekonomi islam akan mengikuti agama islam dalam berbagai aspeknya. Islam adalah sistem kehidupan (way of live) yang akan membawa manusia ke hal yang lebih baik sesuai dengan tujuan hidupnya. Ekonomi islam dibangun untuk tujuan suci, dituntun oleh ajaran islam dan dicapai dengan cara-cara yang ditentukan pula oleh ajaran islam. Oleh karena itu, kesemua hal tersebut saling terkait dan terstruktur secara hirarkis, dalam arti bahwa spirit ekonomi islam tercermin dari tujuannya, dan ditopang oleh pilarnya. Tujuan untuk mencapai falah hanya bisa diwujudkan dengan pilar ekonomi islam, yaitu nilai-nilai dasar (islamic values), dan pilar operasional, yang tercermin dalam prinsip-prinsip ekonomi islam. Dari sinilah akan tampak suatu bangunan ekonomi islam dalam suatu paradigma, baik paradigma dalam berfikir dan berperilaku maupun bentuk perekonomiannya (P3EI UII, 2008).

Termasuk dalam hal mu'amalah telah diatur agar terhidar dari hal yang dilarang. Muamalah dengan pengertian pergaulanhidup tempat setiap orang melakukan perbuatan dalam hubungan dengan orang lain yang menimbulkan hubungan hak dan kewajiban merupakan bagian terbesar dalam aspek kehidupan manusia. Aktivitas muamalah hubungan antara manusia dengan manusia lainnya. Pemahaman yang lebih sempit mengenai muamalah adalah aktivitas ekonomi yang berkaitan dengan manajemen dan bisnis. Perkembangan ekonomi syariah harus terus diperjuangkan, tidak hanya dari segi isi dan objeknya, tetapi juga sisi subjek pelakunya. Para pelaku ekonomi syariah haruslah setiap muslim yang memahami hakikat 
sistem ekonomi Islam, adalah pribadi yang secara lahir batin berjuang menegakkan hukumhukum Allah khususnya di bidang ekonomi. Diantara kiat untuk semakin mendekatkan diri kepada Allah bagi para pelaku ekonomi syariah adalah dengan senatiasa meningkatkan nilainilai keyakinan dan akidah (Fahmi, 2014).

Konsep muamlah yang dibagun dalam ekonomi Islam bertujuan untuk mensejahterahkan seluruh ummat manusia, termasuk menciptakan keadilan, serta pencapaian falah, yaitu kebahagian yang harus merata dan dapat dirasakan oleh semua manusia. Dalam ekonomi Islam kemerataan menjadi penting, harta yang tidak boleh dinikmati hanya segelintir orang saja. Tetapi upaya harta terus berputar dan bisa didistribusikan melalui kegiatan ekonomi, agar semua orang punya peluang yang sama untuk mencapai kesajahteraan ekonomi. Kesejahteraan yang dikehendaki dalam ekonomi Islam sejalan dengan Sustanable Development Goals (SDGs), yang saat ini juga menjadi tujuan secara global. SDGs atau pembangunan yang saat ini terus diserukan untuk pencapaiannya melalui beberabagai kegiatan. SDGs memiliki 17 tujuan dan 169 pencapaian sesuai dengan ketentuan PBB.

Pada 25 September 2015 bertempat di Markas Besar Perserikatan Bangsa-Bangsa (PBB), para pemimpin dunia secara resmi mengesahkan Agenda Tujuan Pembangunan Berkelanjutan (Sustainable Development Goals) sebagai kesepakatan pembangunan global. Kurang lebih 193 kepala negara hadir, termasuk Wakil Presiden Indonesia Jusuf Kalla turut mengesahkan Agenda SDGs. Dengan mengusung tema "Mengubah Dunia Kita: Agenda 2030 untuk Pembangunan Berkelanjutan", SDGs yang berisi 17 Tujuan dan 169 Target merupakan rencana aksi global untuk 15 tahun ke depan (berlaku sejak 2016 hingga 2030), guna mengakhiri kemiskinan, mengurangi kesenjangan dan melindungi lingkungan. SDGs berlaku bagi seluruh negara (universal), sehingga seluruh negara tanpa kecuali negara maju memiliki kewajiban moral untuk mencapai tujuan dan Target SDGs. SDGs dirancang dengan melibatkan seluruh aktor pembangunan, baik itu Pemerintah, Civil Society Organization (CSO), sektor swasta, akademisi, dan sebagainya. Kurang lebih 8,5 juta suara warga di seluruh dunia juga berkontribusi terhadap tujuan dan target SDGs. Tidak Meninggalkan Satu Orangpun merupakan Prinsip utama SDGs. Dengan prinsip tersebut setidaknya SDGs harus bisa menjawab dua hal yaitu, Keadilan Prosedural yaitu sejauh mana seluruh pihak terutama yang selama ini tertinggal dapat terlibat dalam keseluruhan proses pembangunan dan Keadilan Subtansial yaitu sejauh mana kebijakan dan program pembangunan dapat atau mampu menjawab persoalan-persoalan warga terutama kelompok tertinggal. (www.sdg2030indonesia.org).

Tujuan dari SDGs juga dapat dicapai dengan melibatkan banyak lembaga, termasuk diantaranya yaitu lembaga keuangan syariah. Hal ini karena pencapain SDGs sejalan dengan tujuan yang dicapai dalam konsep ekonomi Islam. Ada kesamaan dalam tujuan dan sejalan dengan apa yang ingin dicapai keduanya. United Nations Development Program (UNDP) Indonesia mengadakan Roundtable Discussion dengan Tema: "Leveraging Innovative Financing for Development: Islamic Banking \& Finance for SDGs" mengundang Tazkia untuk berbagi pengalaman penerapan ekonomi dan keuangan Syariah di Indonesia pada 25 September 2018. Murniati Mukhlisin, Ketua STEI Tazkia, hadir menyampaikan betapa Maqashid Syariah memilki tujuan yang sama dengan Sustainable Development Goals (SDGs) yang dituju oleh UNDP. Murniati juga menjelaskan besarnya potensi keuangan syariah di dunia. "Berbagai negara di Eropa seperti Perancis, Jerman, Luxembourg, UK terlebih lagi negara Muslim seperti Iran, Malaysia, UAE, Arab Saudi dan Indonesia memiliki perhatian besar terhadap perkembangan keuangan syariah yang tampak dari pertumbuhan aset", "Dengan dukungan dari UNDP, regulator, perbankan syariah, Fin'Tech, dunia pendidikan, dan lembaga sosial, diharapkan tujuan mulia ekonomi syariah yang juga senada dengan SDGs dapat tercapai dengan sebaik mungkin", kata Murniati menegaskan. (mysharing.co.id). 
Trimulato, dan Nuringsih. Keterkaitan Lembaga Keuangan Mikro Syariah...

Menteri Keuangan (Menkeu) Sri Mulyani Indrawati membuka The 2nd Annual Islamic Finance Conference yang diselenggarakan pada tanggal 23-24 Agustus 2017 di Hotel Royal Ambarrukmo, Yogyakarta. Konferensi ini mengangkat tema "The Role of Islamic Finance in Eradicating Poverty and Income Inequality". Di acara tersebut Menkeu menjelaskan saat ini dunia memiliki tujuan baru, yaitu menciptakan pembangunan yang berkelanjutan (Sustainable Develoment Goals-SDG). Dalam hal ini peran keuangan syariah sangat penting, sesuai dengan tujuan dari negara-negara Islam untuk memberantas kemiskinan dan penyetaraan pendapatan. "Nilai-nilai dalam Islam sejalan dengan tujuan untuk mencapai SDG, namun diperlukan pemikiran-pemikiran yang inovatif dan kreatif untuk mengembangkan instrumen keuangan syariah. Lebih jauh Menkeu menyampaikan bahwa dalam Islam terdapat dua instrumen keuangan yang dapat dimanfaatkan fungsinya untuk mendukung tercapainya SDG, yaitu zakat dan wakaf. "Saat ini yang lebih banyak dikenal oleh masyarakat adalah zakat fitrah, namun untuk zakat mal atau zakat harta belum terlalu banyak yang membayar. Seperti halnya pajak, masih terdapat hambatan untuk mengumpulkan zakat fitrah," Untuk itu, Menkeu berpesan agar Badan Zakat Nasional ataupun lembaga pengelola zakat lainnya dapat lebih mensosialisasikan definisi 'mal' serta menerapkan pengelolaan zakat yang transparan. Selain itu, terdapat kelompok masyarakat yang memiliki kelebihan dan mewakafkan harta dalam bentuk tanah atau bangunan untuk dipergunakan sebagai masjid, sekolah, dan pemakaman. Bangunanbangunan tersebut dapat dimanfaatkan dengan lebih luas dan dikembangkan agar dapat mendukung tujuan mencapai pembangunan yang berkelanjutan.(www.kemenkeu.go.id).

Bank Indonesia terus mendorong peran ekonomi dan keuangan syariah untuk mendukung tercapainya pertumbuhan berkelanjutan (Sustainable Development Goals- SDGs). Potensi besar dimiliki oleh ekonomi dan keuangan syariah, mengingat prinsip-prinsipnya yang menekankan etika, keadilan, dan kesetaraan. Tak hanya instrumen komersial, ekonomi dan keuangan syariah elah merambah pula ke instrumen non-komersial, seperti zakat dan waqaf, sebagai keuangan sosial syariah. Instrumen-instrumen tersebut dapat berperan dalam mendukung berbagai aktivitas produktif, redistribusi kesejahteraan kepada masyarakat kurang mampu sekaligus mendukung pencapaian SDGs.

Demikian disampaikan Gubernur Bank Indonesia, Perry Warjiyo, dalam Peluncuran Prinsip-Prinsip Pokok Tata Kelola Wakaf (Waqf Core Principles) dan Wakaf Uang Berbasis Sukuk (Cash Waqf-Linked Sukuk) bersama Islamic Development Bank (IDB). Acara merupakan bagian dari rangkaian kegiatan Pertemuan Tahunan IMF-Bank Dunia 2018. Ekonomi dan keuangan syariah yang sehat harus didukung oleh struktur regulasi dan tata kelola yang efektif. Ketersediaan standar peraturan yang diterapkan secara efektif, dalam hal ini $W$ aqf Core Principles dan Cash Waqf-Linked Sukuk, sangat penting dalam menciptakan praktik keuangan syariah secara global yang sehat serta mampu menumbuhkan kepercayaan publik. Peluncuran $W$ aqf Core Principles kali ini merupakan langkah strategis lanjutan setelah PrinsipPrinsip Pokok Tata Kelola Zakat (International Zakat Core Principles) yang diluncurkan pada tahun 2016, yang bertujuan untuk meningkatkan tata kelola dan integritas lembaga-lembaga zakat yang lebih baik ketika memberikan layanan kepada masyarakat berpenghasilan rendah. Peran ekonomi dan keuangan syariah untuk mencapai pertumbuhan berkelanjutan dibahas pula dalam diskusi internasional bertema "Mainstreaming Islamic Finance into Global Initiatives: Another Formidable Pillars in Promoting SDGs"..(wnw.bi.go.id).

Keuangan syariah dapat menjadi salah satu solusi dunia. Terutama dalam mencapai target Sustainable Development Goals (SDGs) yang dicanangkan Perserikatan Bangsa-bangsa (PBB). Selain itu, keuangan syariah tidak hanya menjangkau aspek pemberantasan kemiskinan, tetapi juga mencakup peningkatan kesehatan, penyediaan pendidikan yang berkualitas, kesetaraan gender, dan pembangunan infrastruktur. Kemudian, pertumbuhan ekonomi, antisipasi perubahan iklim dan penurunan tingkat ketimpangan pendapatan. "Prinsip-prinsip khas keuangan syariah yang memihak pada pemerataan pendapatan dan berorientasi pada kegiatan sosial lingkungan menjadikan pengembangan sistem keuangan syariah menjadi sangat 
relevan dengan pencapaian target-target SDGs," Muliaman menambahkan, OJK sebagai otoritas sektor jasa keuangan di Indonesia terus mendorong perkembangan sektor keuangan syariah, mulai dari sektor perbankan syariah, IKNB syariah, hingga pasar modal syariah. (wnw. republika.co.id).

Ada banyak instrumen dalam sistem keuangan syariah yang dapat dijadikan jalan untuk pencapaian SDGs, baik itu lembaga keaangan bank ataupun lembaga keuangan non bank. Instrumen yang mungkin juga relevan dalam pencapaian SDGs melalui perwujudan dari kontribusi ekonomi syariah yaitu lembaga keuangan mikro syariah. Lembaga keuangan mikro syariah yang ada saat ini terus berkembang dan keberadaannya menyentuh langsung tataran masyarakat bawah. Lembaga keuangan mikro syariah kegiataannya memberikan pelayanan ke masyarakat bawah, yang tidak memiliki akses untuk lembaga yang lebih besar, tujuannya sama yaitu pencapaian kesejahtaraan masyarakat secara menyeluruh, sejalan dengan tujuan dari hadirnya SDGs.

Dalam upaya mendorong pemberdayaan masyarakat, khususnya masyarakat berpenghasilan menengah ke bawah dan usaha mikro, kecil, dan menengah (UMKM) diperlukan dukungan yang komprehensif dari lembaga keuangan. Selama ini UMKM terkendala akses pendanaan ke lembaga keuangan formal. Untuk mengatasi kendala tersebut, di masyarakat telah tumbuh dan berkembang banyak lembaga keuangan non-bank yang melakukan kegiatan usaha jasa pengembangan usaha dan pemberdayaan masyarakat, baik yang didirikan pemerintah atau masyarakat. Lembaga-lembaga tersebut dikenal dengan sebutan lembaga keuangan mikro (LKM). Tetapi LKM tersebut banyak yang belum berbadan hukum dan memiliki izin usaha. Dalam rangka memberikan landasan hukum yang kuat atas operasionalisasi LKM, pada 8 Januari 2013 telah diundangkan Undang-Undang Nomor 1 Tahun 2013 tentang Lembaga Keuangan Mikro. Lembaga Keuangan Mikro (LKM) adalah lembaga keuangan yang khusus didirikan untuk memberikan jasa pengembangan usaha dan pemberdayaan masyarakat, baik melalui pinjaman atau pembiayaan dalam usaha skala mikro kepada anggota dan masyarakat, pengelolaan simpanan, maupun pemberian jasa konsultasi pengembangan usaha yang tidak semata-mata mencari keuntungan (ojk.go.id).

Tabel 1. Posisi Pertumbuhan Lembaga Keuangan Mikro Syariah Tahun 2018. (dalam Miliar Rupiah)

\begin{tabular}{llccc}
\hline No & Indikator & Februari 2017 & Februari 2018 & Pertumbuhan \\
\hline 1 & Aset & 83,46 & 115,55 & $38,5 \%$ \\
2 & Penempatan Dana & 28,68 & 40,12 & $39,9 \%$ \\
3 & Piutang & 20,63 & 35,57 & $72,4 \&$ \\
4 & Pembiayaan & 8,15 & 12,46 & $52,9 \%$ \\
\hline
\end{tabular}

Sumber: OJK, Statistik Bula nan IKNB Syariah Februari 2018 (data diolah)

Data di atas menunjukkan pertumbuhan dari Lembaga Keuangan Mikro Syariah pada periode Februari 2017 sampai dengan Februari 2018 menunjukkan pertumbuhan dari beberapa Indikator. Pertumbuhan terbesar dialami pada indikator piutang yang tumbuh sebesar 72,4 persen. Kemudian tersebsar selanjutnya pembiayaan (yang berarti menunjukkan mudharabah dan musyarakah), yang tumbuh sebesar 52,9 persen. Adapun pertumbuhan aset dan penempatan dana tumbuh dibawah 40 persen.

\section{LANDASAN TEORI}

Pekerjaan Sosial mempunyai relevansi yang sangat kuat dengan masalah kemiskinan. Sudah berabad-abad profesi ini bergelut dan terlibat dalam penanganan kemiskinan. Secara historis profesi Pekerjaan Sosial boleh dikatakan lahir dari masalah kemiskinan. Profesi ini 
Trimulato, dan Nuringsih. Keterkaitan Lembaga Keuangan Mikro Syariah...

bahkan menempatkan masalah kemiskinan sebagai bidang utama yang ditangani Pekerjaan Sosial. Jika sangat menjunjung tinggi prinsip-prinsip Hak-Hak Azasi Manusia, Pekerjaan Sosial harus berada di garis depan dalam upaya mengatasi kemiskinan. MDGs yang kemudian bergeser ke SDGs merupakan tujuan bersama yang memerlukan pengalawan bersama baik vertical maupun horizontal. (Ishartono dan Santoso, 2016).

Sekar Panuluh dan Meila Riskia Fitri dalam papernya yang berjudul Perkembangan Pelaksanaan Sustainable Development Goals (SDGs) di Indonesia September 2015-September 2016, menyebutkan bahwa Indonesia mengalami kemajuan yang lebih baik dalam hal ketepatan waktu maupun proses yang partisipatif. tantangan yang dihadapi oleh pelaksanaan SDGs tidak hanya seputar dua hal itu saja. Dari segi substansi, ambisi SDGs untuk menghilangkan komponen negasi pembangunan secara tuntas merupakan suatu pekerjaan yang hampir mendekati utopia. Dari segi proses pun, pelaksanaan SDGs di tingkat nasional masih meninggalkan pekerjaan rumah seperti mekanisme akuntabilitas, penerimaan data dari pihak non-pemerintah, dan juga proses partisipasi itu sendiri. Hal ini seharusnya tidak perlu dipandang sebagai beban melainkan tantangan yang harus dihadapi untuk meningkatkan kinerja bagi akselerasi pembangunan nasional Indonesia hingga 2030. Peranan aktif pemerintah tentu menjadi modal utama bagi pelaksanaan dan pencapaian SDGs di Indonesia. (Sekar dan Meila, 2016).

Muhammad Fardan Ngoyo dalam penelitiannya yang berjudul Mengawal Sustainable Development Goals(SDGs); Meluruskan Orientasi Pembangunan yang Berkeadilan menyimpulkan bahwa Tujuan pembangunan berkelanjutan bukanlah sesuatu yang taken for granted yang serta merta harus diikuti tanpa pernah memikirkan bagaimana dampak dan kontribusinya bagi rakyat banyak. Pada intinya proses pembangunan berkelanjutan yang berdasarkan pada tiga komponen yakni sosial, lingkungan, dan ekonomi yang saling terhubung. Tercapainya tujuan dan target SDGs yang akan berlaku mulai tahun 2015 dan akan ditargetkan akan tercapai pada 2030 merupakan pekerjaan yang tidak mudah dan membutuhkan upaya yang serius dari pemerintah. Selain itu, upaya serius dari pemerintah belumlah cukup bila tidak ada dukungan dari berbagai pihak yang menyokong terlaksananya tujuan tersebut. Partisipasi berbagai pihak dibutuhkan dalam upaya memberikan kontribusi yang positif bagi pembangunan berkelanjutan. Pemerintah perlu merangkul pihak lain seperti organisasi masyarakat sipil (NGO), masyarakat, pelaku usaha, hingga kaum muda dalam berpatisipasi dan memberikan kontribusi sesuai dengan kapabilitas masing-masing. Karena, tujuan utama digagasnya pembangunan berkelanjutan adalah bagaimana pembangunan yang mendatangkan kesejahteraan dapat dipertahankan untuk masa depan atau generasi mendatang. (Fardan.2015)

Wahyuningsih dalam penelitiannya yang berjudul Millenium Development Goals (MDGS) dan Sustainable Development Goals (SDGS) dalam Kesejahteraan Sosial. Menyimpulkan Suistainable develoopment goal's(SDG'S) merupakan sebuah dokumen yang akan menjadi sebuah acuan dalam kerangka pembanggunan dan perundingan negara-negara di dunia. Dimana konsep SDG'S ini melanjutkan konsep dari MDG'S yang sudah berakhir di tahun 2015. Pada dasarnya MDG'S dan SDG's punya persaamaan dan kesamaan tujuan yang sama. Yaitu SDG'S melanjutkan cita-cita mulia dari MDG'S yang ingin menanggulangi kelaparan dan kemiskinan di dunia.SDGs ini tidak terpisah dari MDGs, SDGs merupakan bentuk penyempurnaan MDGs. SDGs merupakan kelanjutan dari apa yang sudah dibangun pada MDGs (Millenium Development Goals). SDG's memiliki 5 pondasi yaitu manusia, planet, kesejahteraan, perdamaian, dan kemitraan yang ingin mencapai tiga tujuan mulia di tahun 2030 berupa mengakhiri kemiskinan, mencapai kesetaraan dan mengatasi perubahan iklim. (Wahyuningsih, 2017).

Banyak faktor yang menyebabkan kondisi usaha mikro sulit untuk dapat berkembang. Di antaranya kurangnya modal dan kemampuan sumber daya manusia untuk mengembangkan usaha agar dapat bersaing. Banyaknya persaingan dari usaha yang memiliki modal lebih besar menjadi faktor utama yang menjadi penyebab persaingan yang tidak seimbang bagi usaha 
mikro. Pemerintah perlu untuk melakukan proteksi bagi usaha mikro agar tetap dapat bertahan melalui perda. Umat Islam dapat mengambil peran dengan memberikan pengetahuan yang menambah wawasan melalui penyuluhan kepada masyarakat sebagai bentuk dari muamalah. Pemerintah perlu memperhatikan sistem ekonomi yang lebih sesuai dengan sistem sosial masyarakat Indonesia serta mengevaluasi konsep pembangunan ekonomi dan distribusi yang selama ini masih mengalami ketidakadilan.(Daulay, 2016).

Hasil analisis yang dilakukan kepada nasabah pembiayaan BPRS Prima Mandiri Pamekasan, didapat hasil bahwa terdapat keterkaitan antara pembiayaan dengan kesejahteraan nasabah BPRS. Hal ini di mungkinkan karena ketika nasabah mendapatkan pembiayaan maka hasil usaha akan meningkat. Ketika hasil usaha meningkat maka secara otomatis nasabah dapat meningkatkan kesejahteraan. Peningkatan kesejahteraan dapat diukur dengan maqashid syariah, seperti meningkatnya zakat, infaq, shadaqah nasabah, meningkatnya pemenuhan konsumsi sehari-hari nasabah, terpenuhinya kebutuhan untuk pendidikan, meningkatnya investasi masa depan dan nasabah dapat mengembangkan usahanya. Dengan meningkatnya kesejahteraan nasabah maka dapat dikatakan BPRS Prima Mandiri Pamekasan memiliki peranan yang penting khususnya dalam penyediaan modal. Akan tetapi hendaknya BPRS juga memberikan penyuluhan atau sosialisasi untuk nasabah, baik pelatihan dalam meningkatkan keterampilan, mengatur keuangan, sosiologi agama, sehingga nasabah dapat menjadi lebih baik. (Pramana, 2017).

Keberadaan lembaga bank syariah harus berfokus pada pemerataan kekayaan kepada seluruh masyarakat khususnya kaum miskin yang diharapkan akan memberikan kemampuan daya beli sejalan dengan konsep alquran yaitu zakat. Pemberdayaan dana zakat dalam hal ini sebagai instrumen paradigma, konsepsi dan filisofis sementara bank syariah sebagi instrumen implementatif, operasional empirik yang akan diharapkan berjalan searah menuju masyarakat yang berkesadaran ekonomi ilahiyah dalam rangka mengurai kesenjangan yang semakin melebar. Kesadaran oleh semua unsur dalam menumbuhkembangkan lembaga keuangan syariah serta perannnya dalam pembangunan khususnya mengurai kesenjangan tersebut diperlukan kerja keras serta pemikiran yang kritis dengan meriview kembali keberadaaannya. (Hamid and Haris, 2017).

Adapun perbedaan antara penelitian ini dengan penelitian-penelitian terdahulu yaitu penelitian ini akan menguraikan tentang peran lembaga keuangan dengan keberdaan kegiatan SDGs yang saat ini terus diupayakan pencapaiannya. Kemudian penelitian ini mengungkapakan perkembangan lembaga keuangan mikro syariah dan peran untuk pencapaian SDGs.

Peran Bank Pembiayaan Rakyat Syariah (BPRS), Pelaksanaan BPR yang melakukan usaha berdasarkan prinsip syariah selanjutnya diatur menurut Surat Keputusan Direktur Bank Indonesia No. 32/ 36/ KEP/ DIR/ 1999 tanggal 12 Mei 1999 tentang Bank Perkreditan Rakyat Berdasarkan Prinsip Syariah. Dalam hal ini, secara teknis BPRS bisa diartikan sebagai lembaga keuangan sebagaimana BPR konvensional, dan yang membedakannya adalah operasionalnya yang menggunakan prinsip syariah islam. Hadirnya BPRS sangat mendukunng perkembangan pasar domestik dalam UMKM, sebagaimana fungsinya yang sama dengan perbankan syariah yaitu pengerahan dana masyarakat. BPRS keberadaannya di tengah masyarakat lebih dekat jika di bandingkan dengan perbankan syariah, terlihat jenis usaha yang dilakukan BPRS yaitu untuk usaha yang waktu perputarannya dananya dalam jangka pendek dengan mengutamakan usaha skala menengah dan kecil.

Strategi operasional BPRS tidak bersifat menunggu terhadap datangnya permintaan fasilitas, melainkan bersifat aktif dengan melakukan sosialisasi/ penelitian kepada usaha-usaha yang berskala kecil yang perlu dibantu tambahan modal, sehingga memiliki prospek bisnis yang baik. Sehingga BPRS lebih giat dalam operasionalnya dalam permodalan untuk usaha mikro, kecil dan menengah. Upaya yang rutin dilakukan BPRS berupa aktif membaca dan mengkaji 
Trimulato, dan Nuringsih. Keterkaitan Lembaga Keuangan Mikro Syariah...

pangsa pasar, tingkat kejenuhan serta tingkat kompetitifnya produk yang akan diberi pembiayaan. Pengawasan juga dilakukan terhadap usaha yang mendapatkan modal agar keberadaan modal tersebut dapat dipastikan benar-benar dipergunakan secara optimal dalam usaha sektor riil dan sesuai dengan prinsip syariah. Selama akad masih berlaku maka BPRS terus memantau usaha yang mendapatkan modal tersebut, hingga akhir akad dan menerima bagi hasil (profit and loss sharing).

Perhatian BPRS terhadap perkembangan pasar domestik dalam UMKM terlihat dari berbagai tujuan yang ingin dicapai. Adapun tujuan yang dikehendaki dengan berdirinya BPRS adalah: (Sumitro, 1996). 1) Meningkatkan kesejahteraan ekonomi masyarakat, terutama masyarakat golongan ekonomi lemah yang pada umumnya berada didaerah pedesaan. 2) Menambah lapangan kerja terutama di tingkat kecamatan, sehingga dapat mengurangi arus urbanisasi. 3) Membina semangat Ukhuwah Islamiyah melalui kegiatan ekonomi dalam rangka meningkatkan pendapatan per kapita menuju kualitas hidup yang memadai. 4) Meningkatkan pangsa pasar dalam negeri (ekonomi domestik).

Peran Baitul Maal Wattamwil (BMT) BMT terdiri dari dua istilah, yaitu baitul maal dan baitul tamwil. Baitul maal lebih mengarah pada usaha-usaha pengumpulan dan penyaluran dana yamg non-profit, seperti: zakat, infaq dan sadqah. Sedangkan baitul tamwil sebagai usaha pengumpulan dan penyaluran dana secara komersial. Usaha-usaha tersebut menjadi bagian yang tidak terpiasahkan dari BMT sebagai lembaga pendukung kegiatan ekonomi masyarakat kecil dengan berlandaskan syariah. Secara kelembagaan BMT didampingi atau didukung Pusat Inkubasi Bisnis Usaha Kecil (PINBUK). PINBUK sebagai lembaga primer kerena mengemban misi yang lebih luas, yakni menetaskan usaha kecil. Dalam prakteknya, PINBUK menetaskan BMT, dan pada gilirannya BMT menetaskan usaha kecil. (Raharjo, 1999). Keberadaan BMT merupakan reprensentasi dari kehidupan masyarakat dimana BMT itu berada, dengan jalan ini BMT mampu mengakomodir kepentingan ekonomi masyarakat. Sebagai lembaga keuangan syariah yang bersentuhan langsung dengan kehidupan masyarakat kecil yang serba cukup, ilmu pengetahuan ataupun materi, maka BMT mempunyai tugas penting dalam mengemban misi keislaman dalam segala aspek kehidupan masyarakat. BMT sangat dibutuhkan bagi masyarakat untuk pemberdayaan ekonomi rakyat baik untuk pasar internasional maupun pasar domestik, dan mengatasi masalah ekonomi yang dapat menghambat perkembangan UMKM.

Peran BMT, yaitu menjauhkan masyarakat dari praktek ekonomi non-syariah. Aktif melakukan sosialisasi ditengah masyarakat tentang arti penting sistem ekonomi islam. Melakukan pembinaan dan pendanaan usaha kecil. BMT harus bersikap aktif menjalankan fungsi sebagai lembaga keuangan mikro, misalnya dengan jalan pendampingan, penpembinaan, penyuluhan, dan pengawasan terhadap usaha-usaha nasbah atau masyarakat umum. Serta dapat menghapuskan budaya buruk yang sering terjadi pada masyarakat kecil. Yaitu adanya ketergantungan pada rentenir atau peminjaman dengan bunga yang sangat membebani masyarakat. BMT harus memberikan pelayanan yang lebih baik bagi masyarakat dan memberikan kemudahan dalam pembiayaan tanpa prosedur yang dapat mempersulit pemohon dana. BMT akan menjaga keadilan ekonomi masyarakat dengan distribusi yang merata. (Heri, 2003). BMT sebagai lembaga keuangan yang ditumbuhkan dari peran masyarakat luas, tidak ada batasan ekonomi, sosial bahkan agama. Semua komponen masyarakat dapat berperan aktif dalm pembangunan sebuah sistem keuangan yang lebih adil dan yang lebih penting mampu menjangkau lapisan pengusaha yang terkecil sekalipun.

BMT merupakan organisasi bisnis yang juga berperan sebagai sosial. Sebagai lembaga sosial, Baitul Maal memiliki kesamaan fungsi dan peran dengan Lembaga Amil Zakat (LAZ) atau Badan Amil Zakat milik pemerintah, oleh karenanya, Baitul Maal ini harus didorong untuk mampu berperan secara profesional menjadi LAZ yang mapan. Fungsi tersebut paling tidak meliputi upaya pengumpulan dana zakat, infaq, sedekah wakaf, dan sumber danadana sosial yang lain, serta upaya pentasyarufan zakat kepada gololngan yang paling berhak sesuai 
dengan ketentuan asnabiah (UU nomor 38 tahun1999). Sebagai lembaga bisnis BMT lebih memfokuskan kegiatan usahanya pada sektor keuangan, yakni simpan-pinjam dengan pola syariah. Usaha ini seperti usaha perbankan yang menghimpun dana dari anggota masyarakat dan menyalurkannya kepada sektor ekonomi halal dan menguntungkan. Perbedaannya dengan bank terletak pada obyek dana, jika bank dapat menarik dana dari masyarakat tanpa syarat, maka BMT hanya dapat menarik dana dari masyarakat dengan syarat menjadi anggota atau calon anggota. Namun demikian, terbuka luas bagi BMT untuk mengembangkan lahan bisnisnya pada sektor rill maupun sektor keuangan lain, yang dilarang dilakukan oleh lembaga keuangan bank. Karena BMT bukan bank, maka tidak tunduk pada aturan perbankan. (Ridwan, 2006).

BMT dalam menumbuhkembangkan usaha mikro, kecil dan menengah di lingkungannya merupakan sumbangan yang sangat berarti bagi pembangunan nasional. Bank yang diharapkan mampu menjadi perantara keuangan ternyata hanya mampu bermain pada level menengah ke atas. Sementara lembaga keuangan non-formal yang notabene mampu menjangkau pengusaha mikro, tidak mampu meningkatkan kapitalisasi UMKM. Maka BMT diharapkan tidak terjebak pada dua kutub ekonomi yang berlawanan tersebut. BMT tidak digerakkan dengan motif laba semata, tetapi juga motif sosial. Karena beroperasi dengan pola syariah, sudah barang tentu mekanismen kontrolnya tidak saja dari aspek ekonomi saja atau kontrol dari luar tetapi agama atau akidah menjadi faktor pengontrol dari dalam yang lebih dominan. (Ridwan, 2004). Pembiayaan yang diberikan oleh BMT mengedepankan prinsip kerjasama (Partnership), yakni bentuk pembiayaan kepada anggota atau nasabah. BMT akan menyertakan modal baik uang tunai maupun barang untuk meningkatkan produktivitas usaha. Sistem ini sesungguhnya inti dari LKS. Karena BMT yang memberikan modal usaha, maka BMT bertindak selaku shahibul maal dan anggota atau nasabah sebagai mudharib. Atas dasar transaksi ini BMT akan bersepakat dalam pembagian nisbah bagi hasil, dalam setiap periode akuntansi (laporan usaha) anggota akan berbagi hasil sesuai dengan kesepakan. Dari BMT yang merupakan salah satu instrumen dari lembaga keuangan syariah, dan ekonomi islam secara umum akan membangkitkan UMKM dan peningkatan kualitas pasar domestik. Sehingga keterlibatan UMKM bisa mendapatkan perhatian yang layak terhahadap pembangunan ekonomi nasional.

Tujuan Pembangunan Berkelanjutan atau dalam bahasa Inggris dikenal sebagai Sustainable Development Goals disingkat dengan SDGs adalah 17 tujuan dengan 169 capaian yang terukur dan tenggat yang telah ditentukan oleh PBB sebagai agenda dunia pembangunan untuk kemaslahatan manusia dan planet bumi. Tujuan ini dicanangkan bersama oleh negaranegara lintas pemerintahan pada resolusi PBB yang diterbitkan pada 21 Oktober 2015 sebagai ambisi pembangunan bersama hingga tahun 2030. Tujuan ini merupakan kelanjutan atau pengganti dari Tujuan Pembangunan Milenium yang ditandatangani oleh pemimpin-pemimpin dari 189 negara sebagai Deklarasi Milenium di markas besar PBB pada tahun 2000 dan tidak berlaku lagi sejak akhir 2015.

Pada bulan Agustus 2015, 193 negara menyepakati 17 tujuan berikut ini: Tujuan 1 Tanpa kemiskinan, Pengentasan segala bentuk kemiskinan di semua tempat. Tujuan 2 - Tanpa kelaparan Mengakhiri kelaparan, mencapai ketahanan pangan dan perbaikan nutrisi, serta menggalakkan pertanian yang berkelanjutan. Tujuan 3 - Kehidupan sehat dan sejahtera, Menggalakkan hidup sehat dan mendukung kesejahteraan untuk semua usia. Tujuan 4 Pendidikan berkualitas, Memastikan pendidikan berkualitas yang layak dan inklusif serta mendorong kesempatan belajar seumur hidup bagi semua orang. Tujuan 5 - Kesetaraan gender, Mencapai kesetaraan gender dan memberdayakan semua perempuan. Tujuan 6 - Air bersih dan sanitasi layak, Menjamin akses atas air dan sanitasi untuk semua. Tujuan 7 - Energi bersih dan terjangkau, Memastikan akses pada energi yang terjangkau, bisa diandalkan, berkelanjutan dan modern untuk semua. Tujuan 8 - Pekerjaan layak dan pertumbuhan 
Trimulato, dan Nuringsih. Keterkaitan Lembaga Keuangan Mikro Syariah...

ekonomi, Mempromosikan pertumbuhan ekonomi berkelanjutan dan inklusif, lapangan pekerjaan dan pekerjaan yang layak untuk semua. Tujuan 9 - Industri, inovasi dan infrastruktur, Membangun infrastruktur kuat, mempromosikan industrialisasi berkelanjutan dan mendorong inovasi. Tujuan 10 - Berkurangnya kesenjangan, Mengurangi kesenjangan di dalam dan di antara negara-negara. Tujuan 11 - Kota dan komunitas berkelanjutan, Membuat perkotaan menjadi inklusif, aman, kuat, dan berkelanjutan. Tujuan 12 - Konsumsi dan produksi yang bertanggung jawab, Memastikan pola konsumsi dan produksi yang berkelanjutan. Tujuan 13 - Penanganan perubahan iklim, Mengambil langkah penting untuk melawan perubahan iklim dan dampaknya. Tujuan 14 - Ekosistem laut, Pelindungan dan penggunaan samudera, laut dan sumber daya kelautan secara berkelanjutan. Tujuan 15 Ekosistem daratan, Mengelola hutan secara berkelanjutan, melawan perubahan lahan menjadi gurun, menghentikan dan merehabilitasi kerusakan lahan, menghentikan kepunahan keanekaragaman hayati. Tujuan 16 - Perdamaian, keadilan dan kelembagaan yang tangguh, Mendorong masyarakat adil, damai, dan inklusif. Tujuan 17 - Kemitraan untuk mencapai tujuan, Menghidupkan kembali kemitraan global demi pembangunan berkelanjutan. (wikipedia.org)

Berakhirnya MDGs pada 2015 masih menyisakan sejumlah pekerjaan rumah yang harus diselesaikan pada periode Tujuan Pembangunan Berkelanjutan (Sustainable Development Goals/SDGs) yang akan dilaksanakan sampai dengan 2030. Tujuan Pembangunan Milenium (Millennium Development Goals/MDGs) yang telah dilaksanakan selama periode 2000-2015 memang telah membawa berbagai kemajuan. Sekitar 70 persen dari total indikator yang mengukur target MDGs telah berhasil dicapai oleh Indonesia. Akan tetapi, beberapa indikator yang mengukur target di bidang kesehatan masih cukup jauh dari capaian dan harus mendapatkan perhatian khusus. Target yang belum tercapai di antaranya adalah tingkat kemiskinan nasional. angka kematian bayi, angka kematian ibu, prevalensi gizi buruk, prevalensi HIV dan AIDS serta beberapa indikator terkait lingkungan. Indonesia sebagai salah satu negara yang telah menyepakati penerapan tujuan pembangunan berkelanjutan (SDGs) berkomitmen untuk menyukseskan pelaksanaan SDGs melalui berbagai kegiatan dan telah mengambil langkah-langkah strategis. Sejumlah langkah yang telah ditempuh Indonesia sampai dengan akhir 2016 antara lain (i) melakukan pemetaan antara tujuan dan target SDGs dengan prioritas pembangunan nasional, (ii) melakukan pemetaan ketersediaan data dan indikator SDGs pada setiap target dan tujuan termasuk indikator proksi, (iii) melakukan penyusunan definisi operasional untuk setiap indikator SDGs, (iv) menyusun peraturan presiden terkait dengan pelaksanaan tujuan pembangunan berkelanjutan, dan (v) mempersiapkan rencana aksi nasional dan rencana aksi daerah terkait dengan implementasi SDGs di Indonesia. (BPS.2016)

Tujuan Pembangunan Berkelanjutan (TPB)/Sustainable Development Goals (SDGs) atau Agenda 2030 telah dideklarasikan pada tanggal 25 September 2015, bertepatan dengan berlangsungnya United Nation General Assembly (UNGA) di kantor Perserikatan BangsaBangsa - New York (Amerika Serikat. TPB/ SDGs yang cakupan dan substansinya selaras dengan Nawacita, terdiri atas 17 Tujuan dan 169 Target. Tujuan dan target tersebut menggambarkan visi dan ruang lingkup agenda pembangunan global yang inklusif dan multidimensi, yang akan menjadi panduan bagi komunitas global selama 15 tahun ke depan untuk mewujudkan kesejahteraan masyarakat global. Perserikatan Bangsa-Bangsa melalui Divisi Statistik UN-DESA telah mengeluarkan metadata 241 indikator (versi Maret 2016) untuk mengukur pencapaian target TPB/ SDGs. Berdasarkan Metadata Indikator SDGs Global tersebut, telah dikembangkan Metadata Indikator TPB/SDGs Indonesia yang meliputi 17 TUjuan, 169 Target dan 320 Indikator. (PPN/BAPPENAS. 2017).

Pada 25 September 2015 bertempat di Markas Besar Perserikatan Bangsa-Bangsa (PBB), para pemimpin dunia secara resmi mengesahkan Agenda Tujuan Pembangunan Berkelanjutan (Sustainable Development Goals) sebagai kesepakatan pembangunan global. Kurang lebih 193 kepala negara hadir, termasuk Wakil Presiden Indonesia Jusuf Kalla turut 
mengesahkan Agenda SDGs. Dengan mengusung tema "Mengubah Dunia Kita: Agenda 2030 untuk Pembangunan Berkelanjutan", SDGs yang berisi 17 Tujuan dan 169 Target merupakan rencana aksi global untuk 15 tahun ke depan (berlaku sejak 2016 hingga 2030), guna mengakhiri kemiskinan, mengurangi kesenjangan dan melindungi lingkungan. SDGs berlaku bagi seluruh negara (universal), sehingga seluruh negara tanpa kecuali negara maju memiliki kewajiban moral untuk mencapai Tujuan dan Target SDGs. SDGs Dirancang Secara Partisipatif Berbeda dari pendahulunya Millenium Development Goals (MDGs), SDGs dirancang dengan melibatkan seluruh aktor pembangunan, baik itu Pemerintah, Civil Society Organization (CSO), sektor swasta, akademisi, dan sebagainya. Kurang lebih 8,5 juta suara warga di seluruh dunia juga berkontribusi terhadap Tujuan dan Target SDGs. Tidak Meninggalkan Satu Orangpun (Leave No One Behind) Prinsip utama SDGs. Dengan prinsip tersebut setidaknya SDGs harus bisa menjawab dua hal yaitu, Keadilan Prosedural yaitu sejauh mana seluruh pihak terutama yang selama ini tertinggal dapat terlibat dalam keseluruhan proses pembangunan dan Keadilan Subtansial yaitu sejauh mana kebijakan dan program pembangunan dapat atau mampu menjawab persoalan-persoalan warga terutama kelompok tertinggal. (wmw.sdg2030indonesia.org)

Dalam rangka perumusan SDGs, Sekretaris Jendral PBB juga membentuk Sustainable Development Solutions Network (SDSN). SDSN ini merupakan jaringan independen yang terdiri dari berbagai pemangku kepentingan, akademisi, sektor swasta, lembaga swadaya masyarakat yang ditugaskan untuk mencari solusi praktis untuk tujuan pembangunan dibawah pimpinan Jefrey Sach. Dalam perkembangannya, SDSN mengusulkan 10 tujuan dengan 30 target dan 100 indikator.

Setelah mengusulkan 10 tujuan ini, SDSN pada tanggal 25 Juli 2014 mengeluarkan publikasi yang berjudul Indicators and A Monitoring Framework. For Sustainable Development Goals, Launching A Data Revolution For The SDGs. Dalam publikasi ini SDSN memadukan SDGs usulan OWG dan SDSN. Oleh karena itu, dari publikasi ini diusulkan 17 tujuan SDGs dengan 109 indikator utama dan 111 indikator tambahan. Dalam kajian ini, indikator-indikator yang diusulkan dalam publikasi ini yang dijadikan dasar rujukan. (BPS.2014)

\section{METODE PENELITIAN}

Jenis penelitian yang digunakan studi pustaka yang diperoleh dari beberapa sumber. Penelitian ini bersifat deskriptif kualitatif yang artinya menggambarkan suatu subyek penelitian. Dalam hal ini adalah pertumbuhan BPRS dan BMT di Indonesia, Kemudian desain peran dari kedua lembaga keuangan mikro syariah tersebut dalam pencapaian sustanaible development Goals (SDGs). Konsep keuangan syariah yang sejalan dengan tujuan SDGs.

Jenis data yang digunakan dalam tulisan ini adalah data kualitatif yang bersumber dari data primer dan data sekunder. Data primer berupa sumber data yang langsung memberikan data kepada peneliti atau data yang diperoleh langsung dari lapangan (objek penelitian), sedangkan data sekunder adalah sumber data yang tidak langsung memberikan data kepada pengumpul data (peneliti) atau data yang diambil peneliti sebagai pendukung atas penelitian secara ilmiah yaitu dengan melakukan studi pustaka (penelusuran melalui buku, artikel, jurnal, majalah, internet dan sumber lainnya). (Farizal. 2010).

Data-data yang digunakan penulis antara lain:

1. Teori-teori yang peneliti ambil dari berbagai literatur. Berupa teori yang berkaitan dengan SDGs dan lembaga keuangan syariah.

2. Pengambilan data-data dari hasil yang telah tersaji dari suatu lembaga. Diantaranya data yang diperoleh dari Otoritas Jasa keuangan dan sumber data lainnya.

Batasan dalam tulisan ini difokuskan pada perkembangan BPRS dan BMT di Indonesia, serta pola SDGs. Keduanya sejalan dalam mencapai tujuan untuk kesejahteraan. 
Trimulato, dan Nuringsih. Keterkaitan Lembaga Keuangan Mikro Syariah...

Dengan menyesuaikan pola dari lembaga keuangan mikro syariah BPRS dan BMT dalam kegiatannya mendukung dan sejalan dengan SDGs yang terus dicanangkan

Metode analisis data yang digunakan adalah dengan menggunakan pendekatan kualitatif deskriptif yaitu dengan cara memaparkan perkembangan dari BPRS dan BMT, serta menguraikan konsep Sustanaible Development Goals (SDGs) yang saat ini terus diupayakan oleh pemerintah. Kemudian tujuan dari SDGs yang sejalan dengan tujuan dari lembaga keuangan mikro syariah. Keberadaan lembaga keuangan syariah memiliki peran yang kuat dalam pencapaian SDGs. BPRS dan BMT sejalan dengan tujuan SDGs.

HASIL DAN PEMBAHASAN

Tabel 2. Pertumbuhan Bank Pembiayaan Rakyat Syariah (BPRS) Perkembangan BPRS Desember 2018

\begin{tabular}{llccc}
\hline No & \multicolumn{1}{c}{ Komponen } & Tahun 2017 & Tahun 2018 & Pertumbuhan \\
\hline 1 & Aset & 10.840 .375 & 12.361 .734 & 14,1 \\
2 & Jumlah Kantor & 441 & 495 & 12,2 \\
3 & Jumlah Rekening Nasabah & 1.678 .664 & 1.879 .941 & 11,9 \\
4 & Dana Pihak Ketiga & 6.987 .280 & 8.134 .938 & 16,5 \\
5 & Pembiayaan & 7.763 .951 & 9.084 .467 & 17,1 \\
\hline
\end{tabular}

Sumber : Otoritas Jasa Keuangan (Statistik Perbankan Syariah Desember 2018)

Dari data di atas menunjukkan adanya perkembangan dari Bank Pembiayaan Rakyat Syariah (BPRS) pada periode desember 2017 sampai dengan desember 2018. Pertumbuhan dari beberapa komponen, pertumbuhan terbesar yaitu pembiayaan yang tumbuh sebesar 17,1 persen atau sebesar 9.084.467.000.00. Komponen pertumbuhan terbesar kedua yaitu jumlah dana pihak ketiga yaitu tumbuh sebesar 16,5 persen atau saat ini DPK BPRS sebesar 8.134.938.000.000. Kemudian pertumbuhan terkecil pada komponen Jumlah rekening nasabah yang tumbuh sebesar 11,9 persen. Secara keseluruhan BPRS tumbuh secara baik berdasarkan komponen diatas semuanya tumbuh diatas 10 persen. Meskipun BPRS tumbuh secara baik tetap harus menjaga performa karena persaingan antara lembaga keuangan syariah terus terjadi untuk mendapatkan pangsa pasar.

Tabel 3. Perkembangan Baitul Maal Wattamwil Perkembangan BMT Desember 2018

\begin{tabular}{llccc}
\hline No & \multicolumn{1}{c}{ Komponen } & Tahun 2017 & Tahun 2018 & Pertumbuhan \\
\hline 1 & Aset & 99,96 & 247,34 & 147,4 \\
2 & Dana Syirkah Temporer & 55,17 & 111,16 & 101,5 \\
3 & Modal & 5,30 & 8,04 & 51,6 \\
4 & Sisa Hasil Usaha & 18,96 & 95,28 & 403,5 \\
5 & Cadangan & 1,51 & 1,31 & $-13,2$ \\
\hline \multicolumn{4}{c}{ Sumber : Otoritas Jasa Keuangan (OJK), Statistik Bulanan IKNB Syariah Desember } \\
& 2018
\end{tabular}

Dari data di atas menunjukkan adanya pertumbuhan dari lembaga keuangan yang dikeluarkan oleh OJK untuk periode desember 2017 sampai dengan 2018 menunjukkan pertumbuhan yang sangat baik. Pertumbuhan terbesar pada komponen sisa hasil usaha yaitu sebesar 403,5 persen. Pertumbuhan terkecil pada komponen yaitu modal tumbuh sebesar 51,6 persen, adapun yang mengalami penurunan yaitu komponen cadangan mengalami penurunan sebesar $-13,2$ persen. Dalam performa seperti ini lembaga keuangan mikro syariah harus tetap menjaga keuangan yang dimilikinya khususnya dalam kompetisi mendapatkan pangsa pasar. Kondisi ekonomi yang belum stabil mengharuskan lembaga keuangan syariah untuk bisa meningkatkan cadangan pendapatannya. 
Jumlah pasti BMT tidak diketahui karena banyak diantara mereka tidak terdaftar dan beroperasi secara informal, sementara sebagian lain telah terdaftar sebagai koperasi. Perkiraan tidak resmi menyebutkan jumlah antara 4.500 dan 5.500 di seluruh Indonesia. Namun, BMT yang telah terdaftar sebagai koperasi (tetapi belum ditetapkan lewat peraturan) adalah 1.197 koperasi jasa keuangan syariah (KJKS) dan 2.163 unit koperasi syariah (Unit Usaha Syariah) pada akhir tahun 2014. Hal ini sesuai dengan informasi yang diberikan oleh Kementrian Koperasi dan UKM Indonesia. (Bappenas, Masterplan.2015).

\section{Peran Lembaga Keuangan Mikro Syariah Untuk Sustainaible Development Goals (SDGs)}

BPRS dan BMT sebagai lembaga keuangan mikro syariah memiliki pola dan karateristik yang berbeda dengan Bank Umum syariah dan Unit Usaha Syariah. BPRS dan BMT tidak memiliki produk yang memberikan konsumen lintas transaksi. Tidak ada kartu ATM, tidak ada giro, cek, transfer, mengakibatkan intensitas pertemuan antara nasabah dengan lembaga semakin tinggi. Ketika nasabah memilih menempatkan dananya di BPRS dan BMT maka harus rela untuk datang ke kantor untuk menariknya sendiri. Begitupun dengan pembiayaan jika nasabah memutuskan mengambil pembiayaan dalam setiap waktu tertentu bersedia untuk membayar tagihan pembiayaan di kantor. Tidak ada fasilitas lintas transaksi yang menjadi karakteristik BPRS dan BMT sehingga mengharuskan banyak bertemu dengan nasabah, menjalin kerjasama dan pertemanan dalam mitra bisnis, pola silaturahim menjadi penting bagi BPRS dan BMT dalam mendekati dan mendapatkan nasabah lebih banyak.

Selain itu karakter dari kedua lembaga keuangan mikro syariah BPRS dan BMT yaitu pangsa pasar pada masyarakat segemen mikro, memberikan akses keuangan kepada masyarakat menengah kebawah. Layanan keuangan bagi masyarakat yang tidak memiliki akses ke perbankan. Tujuan dari akses keuangan pada masyarakat kebawah sebagai bentuk agar kesejahteraan dapat dirasakan oleh semua lapisan masyarakat. Harta dapat berputar kepada seluruh lapisan legiatan ekonomi termasuk ekonomi mikro kecil dan menengah. Selain itu tujuan untuk menciptakan kesejahteraan kepada semua masyarakat. Lembaga keuangan syariah diminta agar bisa terus memberikan layanan keuangan masyarakat bawah agar dapat dirasakan dengan harapan meningkatkan taraf hidup masyarakat.

Sustanaible Development Goals (SDGs) atau pembangunan yang berkelanjutan yang telah disepakati untuk dijalankan memiliki 17 tujuan pokok yang ingin dicapai. Kesejahteraan dalam ekonomi menjadi bagian dari tujuan SDGs yang akan dicapai sampai tahun 2030. Dalam mencapai tujuan-tujuan itu melibatkan banyak pihak untuk bisa meralisasikannya, diantara lembaga relevan dan sejalan dengan tujuan SDGs adalah lembaga keuangan mikro syariah. Keduanya memiliki tujuan yang sama yaitu bisa memberikan kesejahteraan kepada masyarakat. SDGs juga memiliki tujuan agar terjadi terjadi pemerataan dalam ekonomi, hadirnya lembaga keuangan mikro syariah memberikan akses bagi pemerataan layanan keuangan bagi masyarakat kelas bawah.

Peran lembaga keuangan mikro syariah dalam mencapai SDGs sangat dibutuhkan khususnya untuk menjangkau masyarakat secara keseluruhan. Bentuk peran dari lembaga keuangan mikro syariah untuk mencapai SDGs yaitu memberikan modal usaha untuk kelas kecil dan menengah dalam rangka mengngkatkan taraf ekonomi semua masyarakat. Kemudian memberikan akses layanan yang baik dan berkualitas bagi setiap masyarakat yang ingin melakukan akses pada produk-produk keuangan, termasuk memberikan produk investasi. Lembaga keuangan mikro syariah harus memahamkan dan mengenalkan bentuk investasi kepada semua masyarakat untuk bisa memperoleh tambahan dan meningkatkan pendapatan ekonomi. 
Trimulato, dan Nuringsih. Keterkaitan Lembaga Keuangan Mikro Syariah...

\section{PENUTUP}

Pertumbuhan lembaga keuangan mikro syariah dalam hal ini adalah BPRS dan BMT pada periode desember 2018 mengalami pertumbuhan yang sangat baik. Beberapa komponen di BPRS mengalami pertumbuhan diatas 10 persen. Pertumbuhan terbesar pada komponen pembiayaan yang tumbuh sebesar 17,1 persen atau sebesar 9.084.467.000.000. Adapun BMT juga mengalami pertumbuhan yang baik, pertumbuhan terbesar pada komponen sisa hasil usaha yaitu sebesar 403,5 persen. Sedangkan komponen cadangan mengalami penurunan sebesar $-13,2$ persen.

Bentuk peran lembaga keuangan mikro syariah bagi pencapaian tujuan dari Sustanaible Goals yaitu BPRS dan BMT memberikan akses layanan keuangan kepada masyarakat bawah, dalam tujuan bukan sekedar untuk meberikan layanan keuangan tetapi juga untuk meningkatkan taraf hidup masyarakat secara keseluruhan. Melaui pemberian modal kepada usaha kecil dan menengah diharapkan bisa meningkatkan kesejahteraan, pendapatan ekonomi dan taraf hidup masyarakat. Lembaga keuangan syariah dan SDGs memiliki kesamaan tujuan untuk hadir mensejahterakan masyarakat, melalui layanan keuangan dan produk lembaga keuangan mikro syariah bisa mewujudkan tujuan SDGs yaitu meningkatkan ekonomi masyarakat dan memberi kesejahteraan. Melalui lembaga keuanga mikro syariah masyarakat bisa memperoleh modal usaha, dan menikmati produk-produk yang bisa menambah pendapatan seperti investasi.

\section{DAFTAR PUSTAKA}

Abu, Fahmi, etc. 2014. HRD Syariah Teori dan Implemtasi. Jakarta: PT. Gramedia Pustaka Utama.

Amiruddin, K. (2017). Konseptualisasi Ekonomi Dan Keuangan Syariah. Al-Mashrafiyah: Jurnal Ekonomi, Keuangan, dan Perbankan Syariah, 1(1).

Badan Pusat Statistik. 2014. Kajian Indikator Sustainable Development Goals (SDGs). Jakarta : Badan Pusat Statistik.

Badan Pusat Statistik. 2016. Potret Awal Tujuan Pembangunan Berkelanjutan (SUSTAINABLE DEVELOPMENT GOALS) di INDONESLA. Jakarta: Badan Pusat Statistik/Statistics Indonesia.

Bappenas. 2015. Masterplan Arsitektur Kenangan Syariah Indonesia. .Jakarta: Bappenas.

Danupranata, Gita. 2006. Ekonomi Islam. Yogyakarta: UPFE-UMY.

Daulay, Raihanah. 2016. Pengembangan Usaha Mikro Untuk Perbedayaan Ekonomi Ummat Islam di Kota Medan. Jurnal MIQOT Vol. XL No. 1 Januari-Juni 2016. Medan: UIN Sumatra Utara.

Fardan, Ngoyo. 2015. Mengawal Sustainable Development Goals(SDGs); Meluruskan Orientasi Pembangunan yang Berkeadilan. Jurnal Sosioreligius Volume I No. 1 Juni 2015. Makassar: Prodi Sosiologi Agama, Jurusan Perbandingan Agama Fakultas Ushuluddin, Filsafat dan Politik UIN Alauddin Makassar.

Farizal. 2010. Pengembangan Kompetensi SDM Perbankan Syariah Melalui Corporate University. Forum Riset Perbankan Syariah II. Yogyakarta: UMY. 
AL-MASHRAFIYAH: Jurnal Ekonomi, Keuangan, dan Perbankan Syariah Volume 3, Nomor 2, Oktober 2019

Hamid, Abdul and Aris. 2017. Peran Perbnkan Syariah Dalam Mengurangi Kemiskinan. Jurnal Syari'ah dan Hukum Diktum, Volume 15, Nomor 1, Juni 2017. Parepare: Jurusan Syariah dan Ekonomi Islam STAIN Parepare.

Ishartono and Santoso Tri Raharjo. 2016. Sustainable Develompent Goals (SDGs) dan Pengentasan Kemiskinan. Volume 2, Nomor 6. Jurnal Share Social Work Journal. Bandung: Universitas Padjajaran.

Kementerian Perencanaan Pembangunan Nasional/ Bappenas. 2017. Metadata Indikator Tujuan Pembangunan Berkelanjutan(TPB)/ Sustainable Development Goals (SDGs) Indonesia Pilar Pembangunan Ekonomi. Jakarta: Kementerian Perencanaan Pembangunan Nasional/ Bappenas.

Minarni. 2015. Falsifikasi Kebijakan Fiskal di Indonesia Perspektif Islam; Menemukan Relevansi Pemikiaran Ibnu Taimiyah Tentang Kenangan Publik Sebagai Potret Khasanah Kebijakan Fiskal Priode Klasik Islam. Yogyakarta: Graha Ilmu.

Muhamad. 2011. Manajemen Keuangan Syariah Analisis Fiqib dan Keuangan. Jakarta: Rajagrafindo.

Munrokhim, Misanam, etc (P3EI). 2008. Ekonomi Islam. Jakarta: Rajawali Pers.

M.Dawan, Raharjo. 1999. Islam dan Transformasi Sosial-Ekonomi. Yogyakarta:Pustaka Pelajar

Panuluh, Sekar and Meila Riskia Fitri. 2016. Perkembangan Pelaksanaan Sustainable Development Goals (SDGs) di Indonesia September 2015-September 2016. Breafing Paper 02. International NGO Forum Indonesian Development.

Pramana, Debby and Rachma Indrarini. 2017. Pembiayaan BPR Syariah Dalam Peningkatan Kesejabteraan UMKM Berdasarkan Maqashid Syariah. Jurnal Ekonomi dan Bisnis Islam, Vol. 3, No. 1, Januari-Juni 2017. Surabaya: Universitas Airlangga.

Ridwan, Muhammad. 2004. Manajemen Baitul Maal Wattamwil (BMT). Yogyakarta: UII Press.

Ridwan, Muhammad. 2006. Sistem dan Prosedur Pendirian Baitul Mal Wattamwil (BMT). Yogyakarta: Citra Media.

Sudarsono, Heri. 2008. Bank dan Lembaga Kenangan Syariah. Yogyakarta: Ekonisia.

Sumitro, Warkum. 1996. Asas-asas perbankan Islam dan lembaga-lembaga terkait (BMUI \& takaful) di Indonesia. Jakarta, Rajagrafindo Persada.

Wahyuningsih. 2017. Millenium Development Goals (MDGS) dan Sustainable Development Goals (SDGS) dalam Kesejabteraan Sosial. Jurnal Bisnis dan Manajemen Volume 11 Nomor 3 September 2017. Jember: Jurusan Manajemen Fakultas Ekonomi dan Bisnis Universitas Jember.

bttps:// wmw.ojk.go.id/id/kanal/iknb/Pages/Lembaga-Kenangan-Micro.aspx, Diakses pada tanggal 8 Juni 2018.

bttps:// wnw.bi.go.id/id/ ruang-media/info-terbaru/Pages/BI-Dorong-Peran-Ekonomi-Syariah-untukPertumbuban-Berkelanjutan.aspx, tanggal 9 Maret 2019.

https://mww.sdg2030indonesia.org/page/8-apa-itu, Diakses tanggal 9 Maret 2019. 
Trimulato, dan Nuringsih. Keterkaitan Lembaga Keuangan Mikro Syariah...

http://mysharing.co/sdgs-sesuai-dengan-keuangan-syariah/, Diakses Tanggal 9 Maret 2019.

bttps:// www.republika.co.id/berita/koran/syariah-koran/16/10/12/oexlx62-kenangan-syariab-solusitarget-sdgs , Diakses tanggal 10 Maret 2019.

https:// wmw.sdg2030indonesia.org/page/8-apa-itu, Diakses pada tanggal 10 Maret 2019.

bttps://id.wikipedia.org/wiki/Tujuan Pembangunan Berkelanjutan, Diakses pada 10 Maret 2019.

bttps:// wmw.kemenkeu.go.id/publikasi/berita/menkeu-nilai-nilai-islam-sejalan-dengan-sdg/, $\quad$ Diakses tanggal 11 Maret 2019. 